\title{
Perception of Low Income Earners on the Performance of Mortgage Institutions in Housing Finance in Lafia, Nasarawa state, Nigeria
}

\author{
Iliyasu Ibrahim ${ }^{1}$, Maryam Salihu Muhammad ${ }^{1}$, Umar Auwal ${ }^{1}$, Daniel Raymond ${ }^{1}$ \\ ${ }^{1}$ Abubakar Tafawa Balewa University \\ Tafawa Balewa Way, P. M. B. 0248, Bauchi, 740272, Nigeria
}

DOI: $10.22178 /$ pos.52-3

JEL Classification: 018

Received 30.10.2019

Accepted 28.11.2019

Published online 30.11.2019

Corresponding Author:

Iliyasu Ibrahim

iliyasuibrahim1515@gmail.com

(c) 2019 The Authors. This article

is licensed under a Creative Commons

Attribution 4.0 License @) (1)

\begin{abstract}
The problem of housing provision by the mortgage industry which includes financing has always being a major concern to the public as a whole. This study investigated the performance of mortgage institutions in housing finance for low-income earners in Lafia metropolis, Nigeria. The objective is to assess the performance of mortgage institutions from low-income earners' perception. Data was collected through a questionnaire survey from 314 low-income earners randomly selected from the targeted population in Lafia metropolis. The data collected were subjected to descriptive statistics with mean ranking to examine the degree of agreement and the significance of the various variables. The study revealed that performance factors such as collateral, loan maturity period and loan requirement, etc. were highly ranked as the most performed area by mortgage institutions. It is recommended that government and stakeholders should reduce the high rate of interest, make mortgage loans accessible and affordable to low-income earners and also increase the funding of mortgage institutions. This study reinforces other research works on the performance of mortgage institutions in housing finance.
\end{abstract}

Keywords: Mortgage institutions; housing; finance.

\section{INTRODUCTION}

The importance of housing finance in any economy cannot be overemphasized. It drives the provision of housing which is more than shelter since it involves all the services and utilities that make a community a livable one. Housing is also one of the best indicators of a person's standard of living and his or her status in society. In spite of the crucial role housing plays like a basic need, it has remained practically inadequately in supply right through human history. An active and buoyant housing sector is an indication of a strong program of national development. It serves as a foundation for and the first step to future economic growth and social development. The housing sector plays a more critical role in a country's welfare than is always recognized as it affects not only the wellbeing of the citizens but also the performance of the other sectors in the country [5].

Mortgage financing represents the important means of housing in the world's developed economies and is also more of a challenge in de- veloping countries. For example, the United Kingdom has the largest mortgage market in Europe which is approximately $25 \%$ of the European market. In Mexico, the housing finance market is in a state of retrenchment, the macroeconomics environments have not been favorable to the development of the primary mortgage market [5]. The Mexican mortgage is highly segmented with a variety of mortgage programs designed for different sectors.

In Nigeria, presently the mortgage sub-sector accounts for $10 \%$ of Nigeria's Gross Domestic Product which means that the opportunities that exist in this sector to boost the nation's economy cannot be exaggerated. The federal mortgage bank of Nigeria puts an estimated over 10 million homes as housing deficit in Nigeria; the implication of this is that with time the mortgage industry will also become large in the Nigerian capital market.

The mortgage industry in Nigeria involves few active players which are often bank subsidiaries and a collection of smaller inadequate mortgage 
institutions. These institutions include semigovernment agencies, mortgage banks, and building societies. Mortgage financing has often been fingered as the most difficult constraints in the Nigerian housing sector. One of the major problems has been the inadequate supply of long term funds which represents the major means of providing mortgages. Thus, the system has relied on compulsory savings into the National Housing Trust Fund (NHTF) scheme. As a result of this, the effort has been made by the regulatory authorities in Nigeria to increase the supply of long term funds for onward lending to prospective homeowners. A few of these efforts include the recent recapitalization of Primary Mortgage Institutions (PMIs) in Nigeria, the Pension and Financial Sector Reforms and the recently promoted Mortgage Backed Securities on the future of investment return in the mortgage industry. This study is set to conduct thorough research into the performance of Mortgage Institutions in Lafia, Nasarawa State, Nigeria.

\section{Literature review}

Overview of Housing. Generally, housing refers to the practice of ensuring that members in a community have a home to live in; it could be a house or some other kind of dwelling, lodging, or shelter. Authors [13], defines a house as a home when it shelters the body and comforts the soul. According to [25], a housing unit is a house, an apartment, a mobile home, a group, or a single room that is occupied (or if vacant, is intended for occupancy) as separate living quarters. However, the UN [24], suggested an explanation of a house is a structurally separate and independent place of abode such that a person or group of persons can isolate themselves from the hazards of climate such as storms and the sun was adopted. The definition, therefore, covered any type of shelter used as living quarters, such as separate houses, semi-detached houses, flats/apartments, compound houses, huts, tents, kiosks, and containers.

Needless to say, housing is one of the most important elementary necessities of humanity in every society; as it ranked next only to food in basic human needs. The housing an individual lives in is a symbol of his social standing, as it represents his accomplishments and social recognition a function of his persona and the measure that represents to a large extent, his self-esteem and social appeal. It is the measure of all the good (or bad) things in life that will come to him and his family [4]. The production of housing and consumption has a direct impact on the socio-economic growth process in diverse ways. In one school of thought, housing is seen to advance economic growth through the expansion of the construction industry and contributes to reducing poverty by increasing the demand for low-skilled workers. Also in most developed economies, where housing equity is of much importance to households, it is found that homeownership has a significant impact on household wealth accumulation in the long run. Also, the fact remains that housing has effects definitely on the social wellbeing of the people.

Overview of Housing Finance. According to [1, 7, 20] the history of housing finance in Nigeria had been a terrible one. The sudden jump from Agrobased to Petro-Naira based economy did not help matters. The assertion that "money was not our problem but how to spend it" accredited to one of our Heads of state, is a summary of a Nation that lacked focus in the formative years. This situation together with unprecedented population growth has remained unchecked ever since. If the foundation is faulty, what can the righteous do? Housing finance was, during the colonial days was limited to the expatriate staff and few selected indigenous senior civil servants in the urban countries. The establishment of Lagos Executive Development Board in 1928; Nigeria Building Society in 1956; formation of State Housing Corporations between 1956 and 1960; National Council of Housing 1971 and, Federal Mortgage Bank of Nigeria 1977 with takeoff capital of N20 million which was later increased to N150 million in 1979 , are very familiar developments in our history.

The World Bank assistance was obtained in 1979. This led to housing projects in eight states of Nigeria with Bauchi State having a share of N24.6 million and Imo State, N63.8 million. The 1980-1985 fourth National Development Programs also proposed a budget of N1.9 billion for housing.

During this period N600 million was spent on housing construction. The failure of these incremental housing production programs and the ever-increasing housing needs led to the promulgation of the National Housing Policy of 1991.

Housing Finance System in Nigeria. The present structure of housing finance in Nigeria can be classified into the following. Informal sector 
(Esusu i.e. Traditional Co-operative System, Credit Co-operatives and family savings); Formal Sector (Non-specialized Institutions and Specialized Housing Finance Institutions). Others (Communities, Associations and Non-Governmental Associations).

The informal sectors of housing funding in Nigeria are traditional Esusu, credit co-operatives, family sources, and individual savings. This sector is usually local and informal in the organization based on trust, love, and friendship. The operation of this sector is difficult to quantify as they operate on the transfer of cash and kind. These include donations of land, building materials, cash assistance or sometimes any of these could be in the form of a loan. The informal sector operation also involves direct labor assistance. It is interesting to note that this sector constitutes a larger proportion of housing providers in Nigeria.

The operation of the formal sector can be classified into Non-specialized Housing Funding Institutions and the Specialized Housing Funding Institutions. Non-Specialized Housing Funding Institutions include the Employees Housing Schemes, Commercial, Merchant Banks and Insurance Companies.

The need to encourage employers of labor to use part of their profit to provide housing for their workers led to the promulgation of the 1979 "Employees Housing Scheme (Special Provision) Decree". The decree requires among others, large employers of labor specifically those who either have not less than 500 persons in their employment in any state of the federation or may be designated as such by the Federal Commissioner (now a minister) with the approval by the Federal Executive Council to establish a housing scheme for their employee. The decree further states that not less than three-quarters of the total accommodation made available in every such scheme shall be for employees who are not executive or senior staff. This is perhaps one of the major housing policy instruments aimed at facilitating the participation of corporate bodies in housing delivery. It has achieved very little. This is partly due to the weak machinery for monitoring which is in a division in the Ministry of Labour [4]. The National Housing Fund (NHF) Decree was promulgated in 1992 aimed at increasing the financial pool that could be used for housing. Nigerians earning from N3000 per annum and above are expected to contribute $2.5 \%$ of their income into NHF.

Before the National Housing Fund Decree, commercial and merchant banks always held a very significant proportion of the mortgage assets within the formal lending sector [21]. Within combined total assets of about N86, 660 million as of December 1989, the commercial and merchant banks held a wider asset base than any other institutional group within the financial sector during this period. Their combined loans and advances portfolio totaled N27.7 million. About $13 \%$ were for real estate. Though with the highinterest rate in the financial market, commercial and merchant banks are now reluctant to finance housing projects except where the houses are to be placed in the market for outright purchase, though this is not good enough for the lowincome earners. The banks are operating with short-term deposits whereas housing finance can only strive in a long term funding environment.

Before the promulgation of the National Housing Fund Decree, insurance companies were obliged to invest not less than $25 \%$ of their life funds in real estate. This was not satisfactorily complied with by these companies because there are many other alternative investments into which they can inject policyholders' funds and achieve better investment returns.

Specialized housing funding institutions in Nigeria include the following: The Federal Mortgage Bank of Nigeria, Primary Mortgage Institutions, Housing Corporations, and Urban Development Bank.

The Federal Mortgage Bank of Nigeria (FMBN) was established in 1977, with the inheritance of the assets and liabilities of the Nigerian Building Society (NBS), which was dissolved, in the same year. The FMBN was created essentially to serve as a wholesale and apex housing finance institution in Nigeria under Decree 7 of 1977. Other institutions created with the responsibilities to serve as housing finance were created through Decree 53 of 1989. They include the Primary Mortgage Institutions such as Building Societies, Housing Associations, and Credit Unions. Among the major responsibilities of the FMBN are the provision of long-term credit facilities to mortgage institutions in the country; encouragement and promotion of development of mortgage institutions at state and national levels supervision and control of the activities of mortgage institutions, mobilization of savings particularly 
through the National Housing Fund, promotion of investment in the manufacturing of building materials and promotion of research on construction and mortgage finance.

The role of the FMBN has also been expanded to back the mortgage finance market with the capital market and develop the viable secondary mortgage market and to mobilize foreign funds into the housing finance sub-sector. The shortcomings of the FMBN operation must have led to the re-examination of the National Housing Policy and the establishment of the National Housing Fund; the two policy instruments of government aimed at enhancing housing delivery in $\mathrm{Ni}$ geria. The National Housing Policy also led to the establishment of Primary Mortgage Institutions (PMI) in Nigeria. Unfortunately within less than five years of the taking off of PMI most of their operations were confronted with problems that resulted in the situation whereby most of the PMI's have their offices closed.

One of the major achievements of the National Housing Policy is its institutional reform which resulted in the establishment of a two-tier formal housing finance system following the promulgation of the Mortgage Institution Decree no. 53 of 1989. Under this arrangement, the FMBN was restricted as the country apex mortgage institution with a supervisory role over a network of PMI. The PMI's are to serve as secondary housing finance institutions. Under the arrangement, the FMBN ceases operation as a retail housing finance institution. This role is to be performed by the PMI's. The role of FMBN henceforth remains as the apex and regulatory body. To perform these functions the FMBN was re-organized into three divisions as follows: The National Housing Fund Division charged with the responsibility for the arrangement of the National Housing Fund. The Regulatory and Inspectorate Division charged with the responsibility of monitoring and regulating housing finance sector operations and Corporate Service Division to provide administrative, accounting and management information services to the core divisions.

The basic functions of the PMI's as stated in the official guidelines of the FMBN are as follows, to ensure equitable distribution of mortgage lending activities all over the country, to operate efficient and effective mortgage institutions, to dictate the level and pace of growth in industry and minimize avoidable fraudulent loses of PMIs and to ensure timely and adequate loan performance to create opportunity for structure expansion in the provision of housing finance.

Based on the report released by the Central Bank, out of about 350 PMIs licensed only 81 are presently declared healthy. To enhance deposit mobilization many PMIs developed attractive products in addition to the National Housing Fund such as social loan, economic loan, commercial loan, mortgage administration deposited institutional deposits, children savings among others.

The first Housing Corporation in Nigeria was the Western Nigeria Housing Corporation established in 1959 after which other State Housing Corporations including the Federal Housing Authority were modeled. They are all established to make available to Nigerians long term credits for housing development. Having realized this shortcoming in their operations many state governments have established property finance agencies, such as Lagos Building and Investment Company (LBIC) to serve the Lagos State Development and Property Corporation (LSDPC) and Ogun State Property Investment Corporation (OPIC) to service the Ogun State Housing Corporation. Virtually all states of the federation have this type of configuration established to promote smooth funding of the housing sector, with operations more favorable to government housing development.

The Urban Development Bank of Nigerian (UDBN) Plc, was established by Decree No 51 of 1992 to foster the rapid development of urban infrastructure throughout the federation through the provision of finance and banking services [27]. It is in the context of infrastructure that the issue of housing finance became part of the bank responsibilities. UDBN cannot be regarded as a bank like any of the regular commercial and merchant banks but a development institution with banking functions.

Housing and Mortgage Finance. The use of either housing loans or mortgage system to acquire dwelling places by Nigerians is of interest because of the level of income and the relatively small size of the mortgage market compared to the size of the financial market. The housing and mortgage finance market should represent a sizeable proportion of the domestic financial market because of the relatively long term structure of mortgage financing. Authors [26], comparing several countries grouped alongside development strata shows that stronger legal rights for both borrowers and lenders, macroeconomic 
conditions and deeper credit information systems are strong factors that can help in deepening the mortgage market in any country. The more the information available and the easier it is to enforce collateral rights (ability to possess), the bigger the market tends to be in all countries, the size of the country notwithstanding. The Nigerian market is especially difficult given the macroeconomic volatility that makes policies to become unstable and therefore unreliable in the long term.

The impact of a well-developed mortgage market in the financial environment can be quantified from the crowding-in effect of the other investments that could lead to exports in Nigeria. Adopting an instrument distributed to nearly all the participants in the mortgage and construction industry, author [17], admits that the market is far from being developed and PMIs operations are bundled. Repayment problems occur where macroeconomic changes affect the income of mortgagors who become unable to meet their financial obligations. Another critical problem of mortgage and housing finance in Nigeria remains the Land Use Decree 1978 which has made the acquisition of title on land a near impossibility. Other problems are inflation, land acquisitions and documentation, the insufficient capital base for the PMIs, financial constraints in the market, high cost of building material and inadequate infrastructure are others.

Housing as an investment and consumer goods constantly yield positive values. Investment in own housing is an important part of personal financial planning which enables the individual to build a hedge against inflation and erosion of currency values. Also, housing has been noted to compel people to save in Nigeria and is not known to affect the BOP adversely [10]. The use of cheap local building materials, for example, the Compressed Stabilized Laterite Bricks (CSLB) have been advocated, but this would need constant encouragement and enlightenment for it to become successful and acceptable [6]. The impact of mortgage finance can be important in poverty reduction, growth and general economic development of the country, especially during construction.

The mortgage sub-sector of the financial system developed more rapidly during the era of universal banking between 2000 and 2010 and was more pronounced after the banking recapitalizations of 2004-2006. The sector enabled the banks to expand their operations with the establishment of PMIs or take-over of insolvent institutions. Thus, the PMIs were strengthened and were able to lend more for mortgage purposes from 2006 since mortgage loans increased from \#2.1billion to $\$ 7.56$ billion and on to $\$ 40.76$ billion in 2007. However, many of these PMIs are frustrated with the management of the NHF and its inability to function as envisaged. Many of the more viable ones especially quoted PMIs have accessed other sources of long term funding externally to provide mortgage loans to Nigerians including partnering with construction firms, Examples are (a) Abbey Building Society plc. (with IFC backed Mortgage Facility Refinance Company and Union Homes plc. (with Swaffer pty of South Africa). One noticeable feature in the housing market is the insurance firms who rather than make their funds available through the FMBN to NHF preferred to directly involved in the construction and mortgage business by lending directly and constructing properties for sale or let.

Challenges of Mortgage Institutions in Housing Finance. Many constraints are limiting the availability of housing finance in Nigeria. Some of these constraints were identified by [9], as unstable macroeconomic conditions, a weak legal framework for property rights, lack of mortgage market infrastructure, and unavailability of funds for long-term finance to promote financial intermediation.

From other sources, including Tiwari and Moriizumi (2003), poor access to finance has been widely identified as the major impediment to having affordable housing in Nigeria. Indeed, the problem of access to finance is recognized as one of the major constraints of housing finance in most emerging economies (Chiquier \& Lea, 2009).

In Nigeria, author [18] using survey analysis and secondary data highlighted that the National Housing Fund policy, land use act, structure of primary mortgage institutions, high-interest rates were some constraints to mortgage financing in Nigeria. Researchers [19], examined the problems of financing real estate development in Nigeria through the administration of questionnaires and simple descriptive analysis. The study revealed that high-interest rates and several other requirements for loan application bedeviled the financing of real properties in Nigeria. The study, therefore, recommended, among others, that the Nigerian Government should en- 
deavor to solve economic problems, such as inflation, to minimize the problems that plague the financing of real estate development. Authors [3], evaluated the performance of the National Housing Fund Scheme in terms of housing delivery in Nigeria. The study adopted secondary data and employed the use of percentiles and t-test as well as Pearson Product Moment of Correlation for analysis. The result indicated that the Primary Mortgage Institutions (PMIs) were not adequate in number and that there was a wide difference between the amounts the mortgagors applied for and the amounts approved.

According to [5], in their work The Assessment of the Contribution of Primary Mortgage Institutions to Housing Finance in Nigeria. Their work identified two factors that contributed to the vague performance record of Federal Mortgage Bank of Nigeria as lack of information to most savings contributors who are willing prospective borrowers and rigid conditions stipulated by Federal Mortgage Bank of Nigeria for obtaining National Housing Fund loan.

Authors [5], further identified that prolonged problems which has constrained adequate and efficient credit delivery to the housing sector as, low-interest rate on National Housing Fund, low level of participation in the National Housing Fund scheme, macroeconomics environment, non-vibrancy of some PMIs, cumbersome legal regulatory framework for land acquisition, the structure of bank deposit liabilities, low capitalization, inadequate mobilization of funds through savings deposits, distractions and failure to confine activities to savings mobilization and mortgage lending and loan defaults.

\section{Methodology}

The research design for this study is a quantitative method, and a field survey was adopted where the questionnaire was used as an instrument for data collection because it provides greater degree responses when administered properly. The population of the study includes all the 16 ministries under the Nasarawa state government, the sample frame of the study is 9,000 and the sample size was determined using table of determining sample size as 368. The study adopted a stratified sampling technique where all the sixteen (16) ministries were stratified into four (4) different strata and each stratum consist of four (4) ministries. From each of the strata, twenty-three (23) respondents were chosen from each ministry making a total of 92 respondents from each stratum using proportionate random sampling. The questionnaires were administered to 360 respondents where 314 were retrieved.

The data collected were analyzed using SPSS version 21. The demographic information of the respondents, Performance of Mortgage Institutions in Housing Finance were analyzed using descriptive statistics, also ANOVA and Post Hoc Test were conducted to see if there are significant differences between permanent, casual, contract and temporary employees' perception on the performance of mortgage institutions in the study area. The reliability test was employed in the study to measure the internal consistency of the instrument using Cronbach's alpha, where values above 0.7 are considered acceptable [14].

\section{RESULTS AND DISCUSSION}

Respondents filled information relating to their background that included gender, age, marital status, level of education, term of employment and their respective ministries (Table 1).

Table 1 - Demographic Information of the Respondents

\begin{tabular}{|l|l|c|c|}
\hline Variables & Options & Frequency & Percentage \\
\hline Gender & Male & 238 & 75.8 \\
\cline { 2 - 4 } & Female & 76 & 24.2 \\
\hline \multirow{4}{*}{ Age } & $18-3$ & 62 & 19.7 \\
\cline { 2 - 4 } & $31-40$ & 189 & 60.2 \\
\cline { 2 - 4 } & $41-50$ & 51 & 16.2 \\
\cline { 2 - 4 } & $51-60$ & 12 & 3.8 \\
\hline Marital Status & Single & 56 & 17.8 \\
\cline { 2 - 4 } & Married & 234 & 74.5 \\
\cline { 2 - 4 } & Divorced & 21 & 6.7 \\
\cline { 2 - 4 } & Separated & 1 & 0.3 \\
\cline { 2 - 4 } Education & Widow & 2 & 0.6 \\
\hline \multirow{4}{*}{$\begin{array}{l}\text { Term of } \\
\text { Employment }\end{array}$} & FSLC & 41 & 13.1 \\
\cline { 2 - 4 } & SSCE & 75 & 23.9 \\
\cline { 2 - 4 } & Diploma & 198 & 63.1 \\
\cline { 2 - 4 } & Temporary & 26 & 8.3 \\
\cline { 2 - 4 } & Permanent & 264 & 84.1 \\
\cline { 2 - 4 } & Contract & 5 & 1.6 \\
\cline { 2 - 4 } & Casual & 19 & 6.1 \\
\hline
\end{tabular}

Table 1 shows that the majority of the respondents are male representing $75.8 \%$ while females represented $24.2 \%$. This means that male respondents have dominated the junior staff 
workforce of various ministries in Nasarawa State.

The table revealed that age 31-40 has the highest percentage of $60.2 \%$ followed by age $18-30$ with $19.7 \%$, then age $41-50$ with $16.2 \%$ and then age 51-60 with 3.8\%. This indicates that age 31-40 dominated the junior staff workforce of Nasarawa state and 51-60 is the least age in the junior staff workforce of the state. At age 31-40 people tend to be eager in their ambition of getting the house as observed from the information in the field survey.

The information obtained shows that $74.5 \%$ of the respondents are married while $17.8 \%$ of them are single, those that are divorced represent $6.7 \%$ followed by those that are a widow with $0.6 \%$ and those that are separated represent $0.3 \%$. Those that are married have the highest percentage while the widow carried the least percentage. Married people dominated the junior staff cadre of Nasarawa State who is mostly concern about how to own houses rather than being tenants as gotten from the field survey.

The level of education determines the level of knowledge and exposure to mortgage issues thus considered important. As indicated by the table Diploma holders has the highest percentage of $63.1 \%$ followed by Senior School Certificate holders with $23.9 \%$ and First School Leaving Certificate holders (FSLC) with 13.1\%. Diploma holders dominated the Nasarawa State workforce of junior staff having carried the highest percentage and first school leavers have the least percentage.

The results show that those on permanent appointments have the highest percentage of $84.1 \%$ followed by those on a temporary appointment with $8.3 \%$ than those on casual with $6.1 \%$ and then those on contract with $1.6 \%$. Those on permanent appointments dominated the junior staff workforce with the highest percentage while those on casual carried the least percentage. The respondents who are on permanent appointment dominated the junior staff cadre and are those that normally contribute to NHF as obtained from the field survey.

The Table 2 below revealed that one of the areas that mortgage institutions performed well is in using low-income earners' salaries as collateral. When the respondents were asked whether mortgage institutions use their salary as collat- eral, the majority of them agreed with the statement. The statement is ranked first in Table 2 with a mean of 4.2994 and a relative important index of 0.8599 .

Table 2- Performance of mortgage institutions

\begin{tabular}{|l|c|c|l|}
\hline \multicolumn{1}{|c|}{ Statement } & Mean & RII & Ranking \\
\hline $\begin{array}{l}\text { Mortgage Institutions use } \\
\text { low income earners' salary } \\
\text { as collateral. }\end{array}$ & 4.2994 & 0.8599 & 1 st \\
\hline $\begin{array}{l}\text { Mortgage loan to low } \\
\text { income earners have long } \\
\text { maturity period. }\end{array}$ & 3.9904 & 0.7981 & 2 nd \\
\hline $\begin{array}{l}\text { Mortgage Institutions' } \\
\text { requirements for mortgage } \\
\text { loans favor the low income } \\
\text { earners. }\end{array}$ & 2.9873 & 0.5975 & 3 rd \\
\hline $\begin{array}{l}\text { Mortgage loan is affordable } \\
\text { to low income earners. }\end{array}$ & 2.9395 & 0.5879 & 4 th \\
\hline $\begin{array}{l}\text { Mortgage loans by } \\
\text { Mortgage Institutions are } \\
\text { accessible to the low } \\
\text { income earners. }\end{array}$ & 2.7229 & 0.5446 & 5 th \\
\hline $\begin{array}{l}\text { Mortgage Institutions } \\
\text { provide the needed loan for } \\
\text { low income earners to own } \\
\text { houses. }\end{array}$ & 2.7134 & 0.5427 & 6 th \\
\hline $\begin{array}{l}\text { Mortgage Institutions } \\
\text { provide the needed } \\
\text { information to savings } \\
\text { contributors. }\end{array}$ & 2.1369 & 0.4274 & 7 th \\
\hline $\begin{array}{l}\text { Conditions stipulated by } \\
\text { FMB for obtaining NHF loan } \\
\text { are not rigid. }\end{array}$ & 1.6051 & 0.3210 & 8 th \\
\hline $\begin{array}{l}\text { The rate of interest charged } \\
\text { by Mortgage Institutions is } \\
\text { low. }\end{array}$ & 1.5191 & 0.3038 & 9 th \\
\hline
\end{tabular}

Responses from the respondents showed that the second-best area of performance by the mortgage institutions is on the maturity period of mortgage loans which is ranked second in the table with a mean of 3.9904 and an RII of 0.7981 .

Another area that the responses indicated the performance of mortgage institutions is on the requirements of mortgage loans by mortgage institutions favoring the low-income earners which were ranked third in the table with a mean of 2.9873 and an $\mathrm{R}^{2}$ of 0.5975 .

On the issue of loan affordability by low-income earners responses from the respondents indicated that mortgage loan is fairly affordable to them and is ranked fourth in the table with a mean of 2.9395 and $\mathrm{R}^{2}$ of 0.5879 . 
On whether a mortgage loan is accessible to lowincome earners the responses showed that the loan is not easily accessible to them and is ranked fifth in the table with a mean of 2.7229 and $\mathrm{R}^{2}$ of 0.5446 .

The table showed that mortgage institutions performed well in terms of loan provided to the lowincome earners to own houses. The statement was ranked sixth in the table with a mean of 2.7134 and $R^{2}$ of 0.5427 .

Also, mortgage institutions failed to perform well in the area of providing the needed information to the low-income earners as the statement was ranked seventh in the table with a mean of 2.1369 and $R^{2}$ of 0.4274 .

Another area that mortgage institutions performed least is on the conditions stipulated by Federal Mortgage Bank for obtaining National Housing Fund loans which are rigid as revealed by the responses obtained from the respondents and are ranked eighth in the table with a mean of 1.6051 and $R^{2}$ of 0.3210 .

On interest rate responses obtained from the respondents showed that mortgage institutions performed worst in this regard. The respondents indicated that the rate of interest is high and it was ranked ninth in Table 3 with a mean of 1.5191 and $\mathrm{R}^{2}$ of 0.3038 .

Table 3 - Performance ANOVA

\begin{tabular}{|l|c|c|c|c|c|}
\hline & $\begin{array}{c}\text { Sum of } \\
\text { Squares }\end{array}$ & df & $\begin{array}{c}\text { Mean } \\
\text { Square }\end{array}$ & F & Sig. \\
\hline $\begin{array}{l}\text { Between } \\
\text { Groups }\end{array}$ & 4.090 & 3 & 1.363 & 2.323 & .075 \\
\hline $\begin{array}{l}\text { Within } \\
\text { Groups }\end{array}$ & 181.943 & 310 & .587 & & \\
\hline Total & 186.033 & 313 & & & \\
\hline
\end{tabular}

The table above shows the ANOVA result of performance. The result shows an $\mathrm{F}$ value of 2.323 which is not significant at a 95 percent confidence interval as indicated by $0.075 \mathrm{p}$-values above 0.05 . This indicated that there are no statistically significant differences among employees in their perception of the performance of mortgage institutions in housing finance. However, the result is marginally significant as the pvalue is slightly above 0.05 and is significant at a 90 percent confidence interval. Authors [14] observed that if there is a marginally significant difference, there might be significant pairwise ad hoc differences and therefore recommended post hoc test to establish such. To establish if such differences exist, a post hoc test was carried out and presented in Table 4 below.

Table 4 - Post Hoc Test of Performance

\begin{tabular}{|l|l|c|c|c|}
\hline $\begin{array}{c}\text { (I) Term of } \\
\text { Employment }\end{array}$ & $\begin{array}{c}\text { (J) Term of } \\
\text { Employment }\end{array}$ & $\begin{array}{c}\text { Mean } \\
\text { Difference } \\
\text { (I-J) }\end{array}$ & $\begin{array}{c}\text { Std. } \\
\text { Error }\end{array}$ & Sig. \\
\hline \multirow{4}{*}{ Temporary } & Permanent & $.39190^{*}$ & .15747 & .013 \\
\cline { 2 - 5 } & Contract & .35983 & .37411 & .337 \\
\cline { 2 - 5 } & Casual & .19726 & .23122 & .394 \\
\hline \multirow{4}{*}{ Permanent } & Temporary & $-.39190^{*}$ & .15747 & .013 \\
\cline { 2 - 5 } & Contract & -.03207 & .34584 & .926 \\
\cline { 2 - 5 } & Casual & -.19464 & .18197 & .286 \\
\hline \multirow{3}{*}{ Casual } & Temporary & -.35983 & .37411 & .337 \\
\cline { 2 - 5 } & Permanent & .03207 & .34584 & .926 \\
\cline { 2 - 5 } & Casual & -.16257 & .38506 & .673 \\
\cline { 2 - 5 } & Temporary & -.19726 & .23122 & .394 \\
\cline { 2 - 5 } & Permanent & .19464 & .18197 & .286 \\
\cline { 2 - 6 } & Contract & .16257 & .38506 & .673 \\
\hline
\end{tabular}

The post hoc test was carried out and the result showed that there is a significant difference in opinions as relating to the performance of mortgage institutions between those on temporary appointments and those on permanents appointments as indicated by a mean difference of 0.39190 which is statistically significant as shown by $0.013 \mathrm{p}$-values which are below 0.05 level. The post hoc test also revealed that there is no significant difference in opinion between those on temporary appointments and those on contract as indicated by a mean difference of 0.35983 which is not statistically significant as shown by $0.337 \mathrm{p}$-values which are above 0.05 level. The result also showed that there is no significant difference in opinion between those on temporary appointments and those on casual appointments as indicated by a mean difference of 0.19726 which is not statistically significant as shown by $0.394 \mathrm{p}$-values which are above 0.05 level.

The post hoc test carried out indicated that there is no statistically significant difference on the perception of those on permanent appointments and those on contract appointments as regard to the performance of mortgage institutions as indicated by a mean difference of -0.3207 which is not statistically significant as shown by $0.926 \mathrm{p}$ values which is above 0.05 significant level. The result also revealed that no significant difference in opinion by those on permanent appointments 
and those on casual as indicated by a mean difference of -0.1964 which is not statistically significant as shown by $0.286 \mathrm{p}$-values which is above 0.05 significant level.

The analysis carried out also indicated that there is no significant difference in perception on the performance of mortgage institutions by those on contract appointments and those on casual appointments as indicated by a mean difference of -0.1627 which is not statistically significant as shown by $0.673 \mathrm{p}$-values which are above 0.05 significant level.

From the foregoing, it can be concluded that there is a significant difference between those on temporary appointments and those on permanent appointments on their perception of the performance of mortgage institutions. However, post hoc analysis revealed that there is no pairwise statistical difference between those on temporary appointments, those on contract appointments and those on casual appointments on the performance of mortgage institutions.

\section{CONCLUSIONS AND RECOMMENDATION}

The findings from the survey carried out indicated that mortgage institutions performed well in the area of using low-income earners salary as collateral but failed in providing loan to lowincome earners to own houses, the result also shows that mortgage loan is partially accessible to the low-income class and that the rate of interest charged by the mortgage institutions is high.

Because of the findings made and conclusions drawn from the study, the following recommendations are provided by the researcher to help enhance and sustain the mortgage industry and also provide recommendations to help in the improvement of Housing Finance options.
The mortgage institutions should adopt more strategies to make their products more known to the market. This could be done by training more officers to reach out to the general public, through flyers and personally explaining to potential clients to get to know the benefits and opportunities they stand to gain by adopting mortgage loans as a strategy to finance their housing projects. Information is very vital to the development of any institution. The low-income class should be well informed about the loan products available to them so that they can make decisions on them. The mortgage institutions should involve in campaign awareness from place to place, use both electronic and print media and also in social media enlightening the low-income group on what they stand to get if they participated fully in the NHF scheme.

The research also recommends a joint talk by the government and the mortgage institutions to lower the interest rate, to reduce the burden that clients complain about mortgage loans. This, in turn, will bring in more clients on board as the majority of people were hindered by the interest rate. The government and all stakeholders in mortgage industries should come together and review the current rate of interest on mortgage loans this will enable the low-income class to obtain the loan at an affordable rate and be able to build their houses. Also, the research recommends that the loan should be made accessible to the low-income class who wishes to access it to finance the housing project.

The research also recommends that mortgage institutions should make mortgage loan requirements very flexible so that low-income earners would not find it difficult in their effort to access the loan product available.

\section{REFERENCES}

1. Abiodun, A. (1999). Housing finance under National Housing Fund. An appraisal paper presented at the General Meeting of the Nigeria Institute of Town Planning.

2. Adedeji, Y. M. D., \& Abiodun O. O. (2012). An Evaluation of Accessibility of Low-Income Earners to Housing Finance in Nigeria. European Scientific Journal, 8(12), 80-95.

3. Adedokun, O. A., Akinradewo, F. O., Adegoke, J. O., \& Abiola-Falemu, J. O. (2011). Evaluation of the Performance of National Housing Fund Scheme towards Housing Delivery in Nigeria. Journal of Emerging Trends in Economic and Management Science, 2(6), 467-471.

4. Agbola, T. (1998). The housing of Nigerians: a review of policy development and implementation in the housing sector. Ibadan: Development Policy Centre. 
5. Akinjare, V., Adetiloye, K., Akhanolu, I., \& Tochukwu, O. (2016). The Assesment of the Contribution of Primary Mortage Institutions to Housing Finance in Nigeria: A Case Study of Union Homes Savings and Loans PLC. Asian Journal of Information Technology, 15(13), 2094-2100.

6. Alagbe, O. A. (2011). Enhancing Sustainable Housing Development in Nigeria Using Compressed Stabilized Laterite Bricks. Journal of Sustainable Development and Environmental Protection, 1(3), 51-59.

7. Arilesere, D. (1997). Housing Finance in Nigeria. A paper presented during Nigerian Institute of Building organised workshop on Affordable Housing, Lagos.

8. Bichi, K. M. (2000). The Role of Federal Mortgage Bank of Nigeria in Financing and Procurement of Housing Infrastructure in Nigeria. Workshop paper organized by the Nigeria Institute of Quantity Surveyors, Abuja. CBN, (1990). Economic and Financial Review. CBN, Lagos.

9. Buckley, R., \& Kalarickal J. (2013). Shelter strategies for the urban poor idiosyncratic and successful, but hardly mysterious. Washington: World Bank.

10. Chatterjee, L. (1982). Housing in Indonesia. Amsterdam: Free University.

11. Chiquier, L. \& Lea, M. (2009). Housing finance policy in emerging markets. Washington: World Bank Publications.

12. Denise, D. \& Wheaton, C. (1992). The Markets for Real Estate and Space: A Conceptual Framework, Journal of the American Real Estate and Urban Economics Association, 20(1), 181-197.

13. Durlauf, S., \& Blume, E. (Eds.). (2018). New Palgrave Dictionary of Economics (2nd ed.). London: Palgrave Macmillan.

14. George, D., \& Mallery, P. (2006). SPSS for Windows Step by Step: A Simple Guide and Reference, 13.0 update (6th ed.). Boston: Pearson.

15. Lea, M. J., Bernstein, S. (1996). The role of the primary mortgage market in the development of a successful secondary mortgage market. Washington: Inter-American Development Bank.

16. Mailafia, 0. (2007). The place and prospects of mortgage financing in the economic and financial systems reforms in Nigeria. A paper presented at year 2007 Board/Staff Retreat. Federal Mortgage Bank Nigeria, Jos, March 23-24, 2007.

17. Nubi, T. O. (2002). Financing Low Income Housing in Nigeria Cities: - Need for Paradigm Shift. In Proceeding, National Conference on Cities in Nigeria, 9-11 October 2002 (p. 135-138.). Ile-Ife: Obafemi Awolowo University. Retrieved from http://196.45.48.50/opendocnew.php?docname=27920\&doctype=doc\&doctitle=\%22Demystif ying-the-Affordable-Housing-Debacle-in-a-Transiting-Economy $\% 22$

18. Oduwaye, L. (2008). Challenges of Housing Finance by Primary Mortgage Institutions in Lagos Nigeria. Retrieved from

https://www.nar.realtor/IRPF.nsf/ca2dae5fa466338d862567e6004ad5ff/cc4930956d3bcf018 62577fa0072bdc8/\$FILE/Nigeria\%20Desktop.pdf

19. Ogedengbe, P. S., \& Adesopo, A. A. (2003). Problems of Financing Real Estate Development in Nigeria. Journal of Human Ecology, 14(6), 425-431. doi: 10.1080/09709274.2003.11905648

20. Okupe, L. (2000). The Role of Private Sector in housing Delivery in Nigeria. Retrieved from http://catdir.loc.gov/catdir/toc/fy038/2003391121.html

21. Onabule, D. (1990). Housing Delivery in Nigeria National Workshop on Housing Delivery in Nigeria. Abuja.

22. Oni, S. A. (2005). Mortgage Institutions and Financing in Nigeria: Performance, Constraints and Prospects. Central Bank of Nigeria Economic and Financial Review, 43(4), 77-82.

23. Tiwari, P., \& Moriizumi, Y. (2003). Efficiency in housing finance: a comparative study of mortgage instruments in Japan. European Journal of Housing Policy, 3(3), 267-288. doi:

$10.1080 / 14616710310001630721$ 
24. United Nations. (1984). Promotion of non-conventional approaches to housing finance for lowincome groups. Nairobi: United Nation Centre for Human Settlements.

25. US Census Bureau. (2010). 2010 US Census United States. Washington: Census Bureau. Retreieved from https://factfinder.census.gov/faces/nav/jsf/pages/index.xhtml

26. Warnock, V. C., \& Warnock, F. E. (2008). Markets and housing finance. Journal of Housing Economics, 17(3), 239-251. doi: 10.1016/j.jhe.2008.03.001

27. Zubairu, M. (1997). Housing Development in Nigeria: The Federal Housing Authority Experience. Workshop on Financing and Procurement of Housing and Infrastructure, The Nigerian Institute of Quantity Surveyors. Lagos. 